\title{
ECONOMIC ASPECTS OF MANURE MANAGEMENT AND PRACTICES FOR SUSTAINABLE AGRICULTURE IN TURKEY
}

\author{
Hasan Yılmaz $^{1^{*}}$, Ludwig Lauwers ${ }^{2,3}$, Jeroen Buysse ${ }^{2}$, \\ Guido Van Huylenbroeck ${ }^{2}$
}

Key words: Manure utilization, manure management, economic assessment, sustainability

\begin{abstract}
Turkish livestock sector plays very important role in the Turkish GDP and the use of manure affects the environment but the farming sector want the farmers to employ the use of more integrated manure practice. The study assessed the economic impacts of integrated manure and chemical fertilizer used and the manure management practices sustainable for Turkish agriculture. Turkey is dependent on foreign countries not only for energy but for chemical fertilizers raw materials. High price of chemical fertilizers is one of the negative impact, manure substitution will lead to stable macro-economy, and environmental friendly economy and agricultural productivity will also impacts. To achieve these impacts, some manure practices suitable for sustainable rural development in Turkey was assessed.
\end{abstract}

\section{Introduction}

The livestock sector in Turkey has been faced with a lot of important development over the years. Cattle numbers significantly increased in the last decades, from 11 million head in 2004 to 14 million head in 2014. This is accompanied with a same increase in manure production as a by-product of the intensive livestock farming. Economically, manure is a substantial resource to be utilized as fertilizer in crop production (Araji et al., 2001), what will potentially decrease the cost of crop production. Although manure use becomes important, especially in regions of high livestock density, chemical fertilizer is nowadays still the major source of nutrients applied to the soil in Turkey. In the meantime, insufficient valorization of available manure may cause environmental problems

\footnotetext{
${ }^{1}$ Department of Agricultural Economics, Isparta University of Applied Sciences, 32260, Isparta, Turkey, Corresponding author: hasanyilmaz@sdu.edu.tr

2 Department of Agricultural Economics, Ghent University, Coupure Links 653, 9000 Gent, Belgium

3 Social Sciences Unit, Institute for Agricultural and Fisheries Research (ILVO), Burg. Van Gansberghelaan 115, 9820 Merelbeke, Belgium
} 
(Unterschultz and Jeffrey, 2001). Solving the problem of the discrepancy between supply and demand of manure by using it appropriately as fertilizer has become therefore a main challenge in Turkish agriculture. There is little information on the supply and demand of nutrient management practices including soil nutrient testing on demanding farms and the level of development of manure storage facilities on supply farms. Unavailability of capital to invest in manure storage, manure treatment technologies and lack of knowledge for nutrient management practices can be the reason for the low rate of supply and demand (OECD, 2008). More in particular for Turkey, manure storage facilities are generally neglected; manure is often randomly and stockpiled in unattended open-air manure storage with huge leakage problems. The environmental effects include water and air pollution, and soil degradation. Also, the manure contributes directly and indirectly to GHG emissions, including through animal physiology, animal housing, manure storage, manure treatments, application of manure and fertilizers (Casey et al., 2006; Monteny et al., 2001). Livestock manure releases $\mathrm{CH}_{4}$ and $\mathrm{N}_{2} \mathrm{O}$ gas. It emissions from manure storage are dependent on environmental conditions, handling systems, and duration of waste management (Rojas-Downing et al., 2017). Manure must be handled aerobically and then anaerobically to release $\mathrm{N}_{2} \mathrm{O}$ emissions, which is more likely to occur in dry waste-handling systems. Steinfeld et al. (2006) reported that $\mathrm{N}_{2} \mathrm{O}$ emissions from stored manure are equivalent to 10 million tons $\mathrm{N}$ per year. On the other hand, one factor that may favor the transition to manure use is the chemical fertilizers' price in Turkey. Those prices are continuously increasing due to the non-renewable energy requirements for fertilizer production what might be an incentive to substitute chemical fertilizers by manure. Encouraging this substitution may lead to non-negligible impacts for Turkish economy, in particular decrease dependency on chemical fertilizers' import. Moreover, beneficial impact on rural development is expected as well as a favorable impact on soil productivity (Yilmaz, 2003). Finally, restoring the manure balance will improve the already prominent Turkish potential for organic agriculture. In order to facilitate a transition towards a more balanced of Turkish manure supply and demand, more information is needed about economics of integrated manure; fertilizer used manure management practices in Turkey. Therefore, the objective of this study was to fill the gap of the existing information on manure supply and demand by putting macro data on livestock nutrient production and cropping needs together. More in particular, the economic cost of nutrient and manure losses due to manure mismanagement practices is assessed. Generated results are discussed within the framework of policy making of sustainable agricultural development. 


\section{Materials and methods}

The secondary data on agricultural sector and animal heads used in this study were obtained from the Turkish Statistical Institute (TURKSTAT, 2015). The secondary data on chemical fertilizer consumption, import and chemical fertilizer price were also obtained from the Turkish Ministry of Food, Agriculture and Livestock (MFAL, 2015). In addition to these data, other data used in this research were obtained from literature such as previous studies of this related issue and articles (Yilmaz et al., 2009; Kizilaslan and Onurlubas 2010; Yilmaz et al., 2010), books (Kacar 1997; Kacar and Katkat 2007) and reports (Goncagul 2003; MARA 2006; LIFE 2006; OECD 2008). In determining nutrient demands of crops and calculating the nutrient balance for Turkey, results obtained from fertilizer experiments in all regions of Turkey by Research Institute of Soil and Fertilizer of General Directorate of Agricultural Research were used and suggested fertilizer amounts were considered (MARA, 2006). The main field crops of Turkey are wheat, barley, maize (corn), maize (silage), alfalfa, sunflower, vetch, cotton, chick peas, sugar beets, lentil, sainfoin, oats, potatoes and rye covering $99.1 \%$ of the total area under field crops production in Turkey. The main fruits of Turkey are olive, hazelnut, grape, apple, apricot, sweet cherry, orange, mandarin, pomegranate, lemon almond, pear, aniseed and cherry covering $80.3 \%$ of the total area under fruits production in Turkey. The main vegetables of Turkey are tomatoes, water melon, melon, green pepper, union (dry), cucumber, eggplant and carrot covering $90.9 \%$ of the total area under vegetables production in Turkey. The average amount of manure produced per animal, the type of animals and nutrient content of manure were calculated by means of coefficients found in Barker et al. (2005). The amount of nutrient losses and weight losses resulting during manure storage in the open area were calculated by taking into account of the coefficients taken from Erkmen and Ozdemir (2012). Additionally, it was calculated that total amount of obtained ash by burning of used manure as cooking and heating in rural areas. Unit prices of chemical fertilizer were calculated according to commercial sale value. Cattle population on the farm was converted to Livestock Units (LU) by means of the coefficients taken from Erkus et al. (1995).

\section{Results and discussion}

\subsection{The amount of nutrient and manure in Turkey}

Table 1 shows the number of animals, manure quantity and energy values of manure in Turkey. Livestock in Turkey is dairy and beef cattle, sheep, goat and poultry with $14.2,31.1,10.3$ and 293.7 million per head in 2014, respectively. They produce an estimated of 141.7, 25.5, 10.4 and 8.8 million tons of manure per year respectively, which in total amounts to 186.5 million tons of fresh manure in 2014. However, this quantity is not entirely collectable. Given an estimated 
availability of the manures by animal for cattle $(65 \%)$, sheep and goat $(13 \%)$ and poultry (99\%) (LIFE, 2006); total collectable fresh manure approximates 105.5 million tons per year. These are rough estimates as data on total manure production are not always reliable; in particular, for sheep and goat farms, accumulation of manure is not well possible because the pasture period of animals within a year is long. In 2014, the livestock sector in Turkey obtained 565,832.1 ton of N, 282 293.1 ton of $\mathrm{P}_{2} \mathrm{O}_{5}$ and 479228.5 ton of $\mathrm{K}_{2} \mathrm{O}$. With these amounts, the capacity of nutrient quantities is 1.33 million tons per year. As can be derived from Table 2, this total amount of nutrients comes respectively for $74.6 \%$ from cattle, $5.6 \%$ from sheep, $2.7 \%$ from goat and $17.1 \%$ from poultry. Ratio of fresh manure to biogas is 33.58 , and $78 \mathrm{~m} 3 /$ year for cattle, sheep and goat and poultry manure, respectively (Kizilaslan and Onurlubas, 2010). With these rates, the capacity for biogas quantities can be estimated to be 3991.8 million $\mathrm{m} 3$ per year. With electricity equivalent values being $2.14 \mathrm{kWh} / \mathrm{m}^{3}$ biogas, the total electricity values for cattle,

Table 1. Total number of animals, amount of manure and energy values of the manure for Turkey

\begin{tabular}{|c|c|c|c|c|c|c|}
\hline \multirow[b]{2}{*}{ Animal } & \multirow[b]{2}{*}{$\begin{array}{c}\text { Animal } \\
\text { Number }^{(a)}\end{array}$} & \multirow[b]{2}{*}{$\begin{array}{l}\text { The amount of } \\
\text { fresh Manure } \\
\text { Produced } \\
\text { (tons/year) }^{(c)}\end{array}$} & \multirow[b]{2}{*}{$\begin{array}{l}\text { The rate of } \\
\text { collectable } \\
\text { fresh } \\
\text { manure (c) } \\
(\%)\end{array}$} & \multirow[b]{2}{*}{$\begin{array}{l}\text { The amount } \\
\text { of collectable } \\
\text { fresh manure } \\
\text { (tons/year) } \\
\text { (c) }\end{array}$} & \multicolumn{2}{|c|}{ Energy equivalents } \\
\hline & & & & & $\begin{array}{c}\text { Biogas } \\
\text { amount } \\
\text { (million } \\
\text { m3/year) }\end{array}$ & $\begin{array}{c}\text { Total } \\
\text { Electricity } \\
\text { equivalents } \\
\text { Value (million } \\
\text { kWh/year) } \\
\end{array}$ \\
\hline Cattle & $14244673^{(\mathrm{b})}$ & 141734496.4 & 65.0 & 92127422.6 & 2315.2 & 4954.7 \\
\hline Sheep & 31115190 & 25514455.8 & 13.0 & 3316879.3 & 1157.6 & 2477.3 \\
\hline Goat & 10347159 & 10450630.6 & 13.0 & 1358582.0 & 399.2 & 854.3 \\
\hline Poultry & 293727620 & 8811828.6 & 99.0 & 8723710.3 & 119.8 & 256.3 \\
\hline Total & 349434642 & 186511411.3 & - & 105526594 & 3991.8 & 8542.5 \\
\hline
\end{tabular}

Sources: own calculations.

(a) TURKSTAT, 2015 and own calculations.

(b) Cattle population on the farm was converted to Animal Units (AU) by means of coefficients (Erkus et al., 1995). ( $\mathrm{AU}=10933$ 926).

(c) In determining of amount of manure produced per animal and collectable fresh manure, were considered values given by (LIFE, 2006) and (Barker et al.,2005). These values are calculated as: $9.95,0.82,1.01$ and 0.03 tons/year, mature cattle, sheep, goat and poultry, respectively.

(d)In determining of amount of biogas produced, were considered coefficients for fresh manure given by Kizilaslan and Onurlubas, 2010. These coefficients are considered as: 33, 58, and $78 \mathrm{~m} 3$ /year, cattle, sheep and goat and poultry, respectively. ${ }^{\left({ }^{(}\right)}$In determining of electricity equivalents value were considered coefficients $\left(1 \mathrm{kWh}=3.6 \mathrm{MJ} ; 22 \mathrm{MJ}\left(1 \mathrm{~m}^{3}\right.\right.$ biogas $)=22 / 3.6 \mathrm{kWh}=6.1 \mathrm{kWh}$; Electrical conversion efficiency $=35 \%$; Therefore $1 \mathrm{~m}^{3}$ biogas $=2.14 \mathrm{kWh}$ (electricity)) given by Bank, 2009 
sheep, goat and poultry wastes in Turkey can be estimated to be approximately 6.5, $0.4,0.1$ and 1.4 billion $\mathrm{kWh} /$ year, respectively. With these quantities, the capacities of electricity equivalents value are 8542.5 million $\mathrm{kWh}$ per year.

2.2.The amount of available nutrient, nutrient losses, nutrient values and energy equivalents according to main utilization purpose and manure management practices in Turkey

In Turkey, usually, the farmers collect manure daily and keep it near the barn. In traditional smallholder animal farming systems of Turkey, the most common system of manure storage includes heaps of manure left in the open area and distributed just before planting. Before application, the manure has rotten in open area on average of 3 months. Both manure as chemical fertilizers are some of the sources soil derived its nutrients from but manure has specific nutrients contents when compare to chemical fertilizer regard to water soluble, it also has a great tendency to leach out leaving the soil by lacking of certain nutrients (Ghosh, 2004). Table 2 illustrates the amount of available nutrients, nutrient losses, nutrient values and energy equivalents according to the purpose of main utilization of manure in Turkey.

Various reasons are behind the inadequate use of manure as a crop fertilizer in Turkey. The first and major one is its use as heating source. Earlier studies reported that $58 \%$ of livestock manure was used as a source of energy for heating in rural areas, $29 \%$ remains unattended and $10 \%$ is used for agricultural purposes while $3 \%$ is used for other purposes (Goncagul, 2003). The quantity of losses during manure practices (burning/heating in rural areas, remains unattended, other purposes and storage of manure in the open areas) is estimated to be about 99.2 million tons per year. With this quantity, the capacity of nutrient equivalents value loss is 832.1 thousand tons per year. Total amount of loss nutrient was determined by taking the utilization practices of manures by nutrient for $\mathrm{N}, \mathrm{P}_{2} \mathrm{O}_{5}$ and $\mathrm{K}_{2} \mathrm{O}$ to be 529 109.6, 113651.2 and 189391.1 tons per year respectively (Table 3). Therefore, the total usable nutrient for $\mathrm{N}, \mathrm{P}_{2} \mathrm{O}_{5}$ and $\mathrm{K}_{2} \mathrm{O}$ in Turkey were estimate to be approximately $36722.5,168641.9$ and 289837.4 tons per year respectively. With these quantities, the capacities of usable nutrient are 495201.8 tons per year. Total amount of loss energy value was determined by taking the utilization practices of manures by energy for biogas, and electricity equivalents to be 1.4 million $\mathrm{m}^{3}$ and 3071.9 million kWh per year respectively.

Manure used in crop production is losing weight during storage for 3 months in an open area. The rate of manure weight and nutrient loss during storage of manure in the open areas were $39.6 \%$ and $59.7 \%$ respectively (Erkmen and Ozdemir, 2012). When these ratios are taken into consideration, total amount of useable manure on crop production was calculated to be 6.4 million tons per year. Additionally, obtained ash by burning of manure for cooking and heating in rural 
areas is important sources of crop nutrients. Rural people or farmers are throwing the manure ash randomly to the environment in Turkey. When incinerating the manure nearly $100 \%$ of the $\mathrm{P}_{2} \mathrm{O}_{5}$ and $\mathrm{K}_{2} \mathrm{O}$ are recovered in the ash but $100 \%$ of the $\mathrm{N}$ disappears (Kacar, 1997). $\mathrm{P}_{2} \mathrm{O}_{5}$ and $\mathrm{K}_{2} \mathrm{O}$ values in manure ash were taken into account in the calculation of useable nutrients quantity. The use of manure in the form of manure ash can complement the use of chemical fertilizer as both manures to improve crop yield. When the use of manure ash as nutrient sources was applied, the reduction in the rate of chemical fertilizers would increase the profit margin of crop production. However, knowledge and information of wide range of manure ash practices is needed so as to reduce the use of chemical fertilizer and integrated nutrient management policy can be achieved (Komiyama at al 2012; Ksawery et al 2010; Pagliari et al 2010).

Table 2. The amount of available nutrient, nutrient losses, nutrient values and energy equivalents according to the purpose of main utilization of manure in Turkey

\begin{tabular}{|c|c|c|c|c|c|c|c|c|}
\hline \multirow[b]{2}{*}{$\begin{array}{l}\text { The purpose of main utilization } \\
\text { of manure }\end{array}$} & \multirow{2}{*}{$\begin{array}{l}\text { The } \\
\text { rate } \\
\text { of } \\
\text { usage } \\
(\%)\end{array}$} & \multirow{2}{*}{$\begin{array}{l}\text { The amount } \\
\text { of used } \\
\text { fresh manure } \\
\text { (million } \\
\text { ton/year) }\end{array}$} & \multicolumn{4}{|c|}{$\begin{array}{l}\text { Nutrient content } \\
\text { in manure (tons) }\end{array}$} & \multicolumn{2}{|c|}{ Energy equivalents } \\
\hline & & & $\mathrm{N}$ & $\mathrm{P}_{2} \mathrm{O}_{5}$ & $\mathrm{~K}_{2} \mathrm{O}$ & Total & $\begin{array}{l}\text { Biogas } \\
\text { Amount } \\
\text { (million } \\
\text { m3/year) }\end{array}$ & $\begin{array}{c}\text { Electricity } \\
\text { equivalents } \\
\text { Value } \\
\text { (million } \\
\text { kWh/year) }\end{array}$ \\
\hline for burning/heating in rural areas & 58 & 61.2 & 328182.6 & 163730.0 & 277952.5 & 769865.1 & 2315.2 & 4954.7 \\
\hline $\begin{array}{l}\text { The amount of nutrient that remaining } \\
\text { in manure ash after burning of manure }\end{array}$ & - & - & 0 & 163730.0 & 277952.5 & 441682.5 & - & - \\
\hline $\begin{array}{l}\text { remains unattended } \\
\text { for crop production } \\
\text { for other purposes }\end{array}$ & $\begin{array}{c}29 \\
10 \\
3\end{array}$ & $\begin{array}{l}30.6 \\
10.6 \\
3.2\end{array}$ & $\begin{array}{l}164091.3 \\
56583.2 \\
16975.0\end{array}$ & $\begin{array}{l}81865.0 \\
28229.3 \\
8468.8\end{array}$ & $\begin{array}{l}138976.3 \\
47922.9 \\
14376.9\end{array}$ & $\begin{array}{l}384932.6 \\
132735.4 \\
39820.6\end{array}$ & $\begin{array}{l}1157.6 \\
399.2 \\
119.8\end{array}$ & $\begin{array}{l}2477.3 \\
854.3 \\
256.3\end{array}$ \\
\hline Total & 100 & 105.6 & 565832.1 & 282293.1 & 479228.5 & 1327353.7 & 3991.8 & 8542.5 \\
\hline $\begin{array}{l}\text { The amount of manure loss (tons/years) } \\
\text { The amount of nutrient loss (tons) (c) }\end{array}$ & $\overline{-}$ & 99.2 & 529109.6 & 113651.2 & 189391.1 & 832151.9 & $\overline{-}^{-}$ & - \\
\hline Energy equivalents of manure loss & - & - & - & - & - & - & 1435.5 & 3071.9 \\
\hline The amount of usable nutrient/energy & - & 6.4 & 36722.5 & 168641.9 & 289837.4 & 495201.8 & 2556.3 & 5470.6 \\
\hline $\begin{array}{l}\text { Source: own calculations } \\
\text { (a) In determining of purposes of ma } \\
\text { (b) Nitrogen value in manure ash and } \\
\text { (c) In determining of nutrient losses } \\
\text { weight }(39.6 \%) \text { resulting during ma } \\
\text { Ozdemir, } 2012 \text {. }\end{array}$ & iza & a crop & ( & 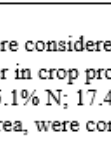 & 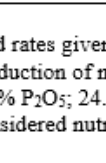 & (n) & 03. & $\begin{array}{l}\text { ent losses } \\
\text { aanure } \\
\text { and }\end{array}$ \\
\hline
\end{tabular}

2.3. Cost of nutrient losses due to manure management practices in Turkey

Table 3 shows the cost of nutrient and energy losses due to manure management practices in Turkey. Values of manure when comparing manure to chemical fertilizers were converted to total manure nutrients to available nutrients by using the availability coefficient. Current chemical fertilizer prices for $\mathrm{N}, \mathrm{P}_{2} \mathrm{O}_{5}$ and $\mathrm{K}_{2} \mathrm{O}$ are as follows: $\$ 401.64, \$ 502.05$ and $\$ 892.53$ per ton respectively. These values do not cover hauling, handling and application costs. Given the estimated value for nutrient losses due to manure mismanagement practices of about 832 thousand tons per year, this is equal to about 1.79 million tons of chemical fertilizer nutrient equivalents or a value of $\$ 932.8$ million per annum. It 
may also be said that this value is approximately as much as the value ( $\$ 1.7$ billion) in half of chemical fertilizer import for one year in Turkey (MFAL, 2015). The quantity of electricity loss due to manure mismanagement practices was estimated to be about 3 billion $\mathrm{kWh}$ per year or $\$ 1.9$ million per annum. Increases in price of chemical fertilizers having a very high level of non-renewable energy requirements and continuing in this way are inevitable. Also, Turkey is dependent on foreign countries for the energy and raw materials for fertilizers (SPO, 2000). In addition, increasing fertilizer prices in Turkey increases the importance and necessity of manure usage for decreasing the cost, protecting and increasing the soil productivity in agricultural production. If the opportunities of benefiting manure increases, not only Turkey's increasing import load in chemical fertilizer industry will decrease but it will also accelerate rural development since it will increase manure investments in rural areas (Yilmaz, 2003). With the increase of the usage of fertilizer with integrated manure, meeting this need in farm system as manure will provide economic benefits by less use of fertilizer. Since manure usage is important for providing sustainable agriculture and environmentally friendly production, it will contribute to the environmental protection.

Table 3. Estimating the economic costs and amount of nutrient losses of manure in Turkey

\begin{tabular}{|c|c|c|c|c|c|c|c|}
\hline \multirow[b]{2}{*}{ Nutrients } & \multirow{2}{*}{$\begin{array}{c}\text { The } \\
\text { amount of } \\
\text { nutrient } \\
\text { loss (tons) }\end{array}$} & \multicolumn{2}{|c|}{ Chemical Fertilizer equivalents } & \multirow{2}{*}{$\begin{array}{l}\text { Unit } \\
\text { price } \\
\text { (US\$ t) ta) }\end{array}$} & \multirow{2}{*}{$\begin{array}{l}\text { Cost of } \\
\text { Nutrient loss } \\
\text { (million } \\
\text { US\$) }\end{array}$} & \multicolumn{2}{|c|}{ Energy equivalent of manure loss } \\
\hline & & $\begin{array}{l}\text { The type of chemical } \\
\text { fertilizer }\end{array}$ & $\begin{array}{l}\text { Equivalents } \\
\text { (tons) }\end{array}$ & & & $\begin{array}{l}\text { The amount of } \\
\text { electricity loss } \\
\text { (million } \mathrm{kWh} / \text { year) }\end{array}$ & $\begin{array}{c}\text { Cost of electricity } \\
\text { loss } \\
\text { (million US\$) }^{\text {(b) }}\end{array}$ \\
\hline $\mathrm{N}$ & 529109.6 & Urea $(\% 46)$ & 1150238.3 & 401.64 & 462.0 & - & - \\
\hline $\mathrm{P}_{2} \mathrm{O}_{5}$ & 113651.2 & Triple superphosphate (43\%) & 264305.1 & 502.05 & 132.7 & - & - \\
\hline $\mathrm{K}_{2} \mathrm{O}$ & 189391.1 & Potassium sulfate $(50 \%)$ & 378782.2 & 892.53 & 338.1 & - & - \\
\hline Total & 832151.9 & - & 1793325.6 & - & 932.8 & 3071.9 & 1.9 \\
\hline
\end{tabular}

2.4.The nutrient demand by crop, the nutrient balance and the rate of nutrients demand for manure and chemical fertilizer

To calculate the nutrient demand and balance for Turkish crops, we started from the amount of fertilizer recommended by the Central Research Institute of Soil Fertilizer and Water Resources of Republic of Turkey Ministry of Food, Agriculture and Livestock. Crops that have the high demand of nitrogen amounts requires nitrogenous manure. Starting from the areas of the different crops, it can be estimated that nitrogen is used mainly for Crops such as wheat and barley $(53 \%)$, potatoes, citrus fruits, corn, cotton and sugar beets require high level of nitrogen and that are mostly grown in Turkey (MARA, 2006). In total, it was calculated that the quantity of nutrient demand is 5079373.8 tons/year. The percentages of nutrient demand by crop category of field crops, fruits and 
vegetables are $79.1 \%, 17.5 \%$ and $3.4 \%$ respectively (TURKSTAT, 2015; MFAL, 2015). Most of the Turkish livestock farms do not have sufficient land (Oskam et al., 2004). This leads to surplus quantity of manure in farms where animals are raised. This leads to inefficient use of manure nutrients in Turkey and harmful environmental influence of livestock farming. This surplus depends on the level of livestock density, the manure management practices and amount of liquid and solid manure produced.

Data on the crop nutrient balance is presented in Table 4. The nutrient demand for crop production was approximately 5.1 million tons. The estimated amount of nutrients from the chemical fertilizer and manure were 2.3 million tons and 495.2 thousand tons respectively. The rate of nutrients demand of Turkey by manure and chemical fertilizer were $9.7 \%$ and $45.5 \%$ respectively. The field calculations reveal that the available amount of nutrients obtained from manure in 2014 is equivalent to 36.7 tons of nitrogen $(\mathrm{N}), 168.6$ tons of phosphate $\left(\mathrm{P}_{2} \mathrm{O}_{5}\right)$ and 28.8 tons of potash $\left(\mathrm{K}_{2} \mathrm{O}\right)$. The ratio of manure meeting the crop nutrient demand for $\mathrm{N}$ and $\mathrm{P}_{2} \mathrm{O}_{5}$ were 0.9 and $18.9 \%$ respectively. Ratio of chemical fertilizer meeting crop nutrient requirement for $\mathrm{N}$ and $\mathrm{P}_{2} \mathrm{O}_{5}$ were 39.9 and $69.9 \%$ respectively (Table 4). It is calculated that the annual total nutrient deficit was about 2.2 million tons. According to calculations, $\mathrm{N}$ deficit occur about 2.4 million thousand tons and 98,963.1 thousand tons $\mathrm{P}_{2} \mathrm{O}_{5}$ deficit (Table 4). It is clear that even if all manure from livestock production would be used for crop production, not all nutrient demand for crop production can be met in Turkey. This shows the need for proper management practices and storage conditions for manure. It is clear that present nutrient losses due to poor manure management practices lead to both economic and environmental losses. Current manure and fertilizer management practices do negatively affect soil fertility and crop yield in Turkey.

Soil nutrients content of Turkey is lower than the European countries when calculated even with more intensive farming (De Clercq et al 2001). Better manure management practices, better storage facility of manure, rationalized fertilization based on plant requirements and soil manure analysis were some of the several measures suggested in order to improve nutrient management on farms even with more intensive farming (Swensson, 2003; D'Haene, 2007). The use of chemical fertilizer increased rapidly before 1980 as more acreage and crop production increases with hybrids which have different response to fertilizer use in Turkey.

Turkey's chemical fertilizer production, imports and consumption were respectively 1.38, 2.31 and 1.16 million tons in 2014 (MFAL, 2015). The supply of chemical fertilizer in Turkey depended historically largely on imports. More than 50 percent of chemical fertilizer consumption came from imports in 2014. Because domestic production capacity is limited and any increase in chemical fertilizer demand must be met by imports. This might of course be related with the high 
prices paid for chemical fertilizer by the farmers. In this regard, some studies on manure logistic have shown that profitability calculations of different methods of manure application and processing from livestock farms which time and money consumption is needed for farm economy. The mechanical manure separation is a manure processing technique which has several advantages such as odor reduction as well as logistic and crop husbandry related benefits. Manure processing is found to be a major issue in livestock production; it demands high investments especially for storage facilities and logistics (Pellervo et al., 2013).

Table 4. Nutrient balance, demand and supply by using manure and chemical fertilizer of Turkey

\begin{tabular}{|c|c|c|c|c|c|c|c|}
\hline Nutrients & $\begin{array}{l}\text { Nutrient } \\
\text { demand } \\
\text { (Tons) } \\
\text { (A) }\end{array}$ & $\begin{array}{l}\text { Nutrient supply } \\
\text { from manure } \\
\text { (tons) (B) }\end{array}$ & $\begin{array}{c}\text { Ratio to meet } \\
\text { from manure } \\
\text { of nutrient } \\
\text { demand }(\%)\end{array}$ & $\begin{array}{c}\text { Nutrient supply } \\
\text { from chemical } \\
\text { fertilizer } \\
\text { (tons) }{ }^{\mathrm{a}}(\mathrm{C}) \\
\end{array}$ & $\begin{array}{c}\text { Ratio to meet } \\
\text { from chemical } \\
\text { fertilizer of nutrient } \\
\text { demand }(\%)\end{array}$ & $\begin{array}{c}\text { Total } \\
\text { nutrient } \\
\text { supply (tons) } \\
(\mathrm{D})=(\mathrm{B})+(\mathrm{C})\end{array}$ & $\begin{array}{c}\text { Nutrient } \\
\text { Balance } \\
\text { (tons) } \\
(\mathrm{E})=(\mathrm{A})-(\mathrm{D})\end{array}$ \\
\hline $\mathrm{N}$ & 4017551.4 & 36722.5 & 0.9 & 1584237.0 & 39.4 & 1620959.5 & $\begin{array}{c}-2396 \\
592.0\end{array}$ \\
\hline $\mathrm{P}_{2} \mathrm{O}_{5}$ & 890387.0 & 168641.9 & 18.9 & 622782.0 & 69.9 & 791423.9 & -98963.1 \\
\hline $\mathrm{K}_{2} \mathrm{O}$ & 171366.4 & 289837.4 & 169.1 & 105705.0 & 61.7 & 395542.4 & 224176.0 \\
\hline Total & 5079304.8 & 495201.8 & 9.7 & 2312724.0 & 45.5 & 2807925.8 & $\begin{array}{l}-2271 \\
379.1 \\
\end{array}$ \\
\hline
\end{tabular}

Land application of manure has shown that the major issue of transporting manure is the cost of hauling and handling. As fuel cost rises, the cost of transportation also increases. Transporting manure is only feasible if the price of chemical fertilizer raises enough to make hauling manure a cheaper option (Nowak et al., 1998). Many studies showed that certain management factors influence decomposition of manure and nutrients losses and these can be controlled by improved management of the manure during collection and storage as well (Tittonel, 2010). Researches showed that manure applied along with a reduced rate of NPK applications was able to reduce the chemical fertilizers used as much as $50 \%$. Also, using manure as a fertilizer in the crop production of farms will decrease the cost of production. With the increase usage of fertilizer with integrated manure, meeting this demand from farm system as manure will provide economic benefits by less use of fertilizer. In a country like Turkey which have very high amount of import power and foreign dependency on fertilizer, it is a luxury waste of resources not to use the tools benefiting manure and not to give enough attention to it. Primary issue of even the producers who get the highest productivity and have the biggest land size in Turkey the fertilizer is so expensive to them. Moreover, the importance of the subject also increases when we consider manure demand whose importance will increase more because of Turkey's organic agricultural potential. The studies performed in this subject are in the form of 
supporting these findings. It is unrealistic to expect from the farmers to compete while using very expensive fertilizers for crops production (Yilmaz, 2003; Yilmaz et al., 2009). If Turkey will create a highly competitive agricultural sector, chemical fertilizer and manure problem must be solved.

\subsection{EU nitrates directive and chemical fertilizers and manures applications in Turkey}

Environmental friendly policies for management of limited resource or pollution prevention can be intervened. Manure used regulations and management is very common in environmental policy design. This approach will be appropriate pollution damage correlates to solely to the manure used. The mismanagement and over-applied of manure leads to excessive nitrogen and phosphate emissions (Van der Straeten et al., 2011).

The adoption of "Acquis Communautaire" emphasizes the integration of environmental concerns and good practices in manure management. A Nitrate Directive was adopted, as part of the goal to harmonize with EU policies in Turkey but there is the need to outline the duties of the organizations responsible for the directive. Nitrogen leaching has over the decades been the one of the major challenge facing the aquatic and ecological environments. A number of EU Directives, national and international regulations have influence agricultural practices especially in livestock sector (Asai et al., 2014). Government has to take action against excessive application of manure and chemical fertilizer in order to achieve the European Nitrate Directive (91/676/EC) and the Water Frame Directive (2000/60/EC).

Tables 5 show the amount of NPK in applied chemical fertilizers and manure in Turkey. Chemical fertilizer used is $116.6 \mathrm{~kg}$ per hectare. There are $79.9 \mathrm{~kg} \mathrm{~N}$, $31.4 \mathrm{~kg} \mathrm{P} \mathrm{P}_{2} \mathrm{O}_{5}$, and $5.3 \mathrm{~kg} \mathrm{~K}_{2} \mathrm{O}$ in chemical fertilizer consumption per hectare. The use of chemical fertilizer in Turkey is lower when compare with many developing countries. Netherland has $665.5 \mathrm{~kg} / \mathrm{ha}$, Egypt is $624.8 \mathrm{~kg} / \mathrm{ha}, 373.2 \mathrm{~kg} / \mathrm{ha}$ in Japan, $301.5 \mathrm{~kg} / \mathrm{ha}$ in China whiles $287.5 \mathrm{~kg} / \mathrm{ha}, \quad 205.4 \mathrm{~kg} / \mathrm{ha}, \quad 180.1 \mathrm{~kg} / \mathrm{ha}$, $160.8 \mathrm{~kg} / \mathrm{ha}, 126.4 \mathrm{~kg} / \mathrm{ha}, 121.4 \mathrm{~kg} / \mathrm{ha}$ and $115.4 \mathrm{~kg} / \mathrm{ha}$ for England, Germany, France, USA, Italy, India and Greece respectively (FAOSTAT, 2013). In Turkey, nutrient is supplied as manure $25 \mathrm{~kg}$ per hectare. There is $1.9 \mathrm{~kg}$ nitrogen, $8.5 \mathrm{~kg}$ phosphate, and $14.6 \mathrm{~kg}$ potassium per hectare in nutrient supplied as manure. The total nutrient supplied is $141.6 \mathrm{~kg}$ per hectare. There is, $81.7 \mathrm{~kg}$ nitrogen, $39.9 \mathrm{~kg}$ phosphate and 19.9 potassium in total nutrient supplied.

The manure application standards limit the manure use on the land. For instance the EU standard is $170 \mathrm{~kg} \mathrm{~N} / \mathrm{ha}$ of Nitrates Directive (Directive 91/676/EEC1). Manure which cannot be used or utilized is considered as surpluses. In intensive and highly productive livestock areas, this limit may become a 
production constraint. Excessive amount of $\mathrm{N}$ application $(>170 \mathrm{~kg} / \mathrm{ha})$ of chemical fertilizer and manure was recorded in certain parts of Turkey. Excessive and long use of manure in the farm can make the soil highly nitrogenous and this should be taken into consideration when planning. In order to reduce the nitrate leaching and soil conservation for both water and fertilizers, it is imperative to optimize the water and fertilizer application to match the crop requirements of Turkish crops (Karyotis et al., 2014).

There is little manure recycle thus extra demand for chemical fertilizer in Turkey. This is another constrain and a search for better substitution of manure for chemical fertilizer is on course. The attention should be more focused on efficiency increases when taking the current policy into consideration, per the absorption efficiency progress and better substitution of chemical fertilizer and manure. The chemical fertilizer is generally applied to meet the crop nutrients requirements and excess application of $\mathrm{P}$ mostly with manure from animal farms production. Another problem is the difficulty in application of small amounts of manure and extra cost for handling the remaining manure on the farm.

Table 5. Amount of NPK in applied chemical fertilizers and manures in Turkey

\begin{tabular}{cccc}
\hline Nutrients & $\begin{array}{c}\text { Nutrient supply as } \\
\text { chemical fertilizer }(\mathrm{kg} / \mathrm{ha})\end{array}$ & $\begin{array}{c}\text { Nutrient supply } \\
\text { as manure }(\mathrm{kg} / \mathrm{ha})\end{array}$ & $\begin{array}{c}\text { Total nutrient } \\
\text { Supply }(\mathrm{kg} / \mathrm{ha})\end{array}$ \\
\hline $\mathrm{N}$ & 79.9 & 1.9 & 81.7 \\
$\mathrm{P}_{2} \mathrm{O}_{5}$ & 31.4 & 8.5 & 39.9 \\
$\mathrm{~K}_{2} \mathrm{O}$ & 5.3 & 14.6 & 19.9 \\
\hline $\mathrm{NPK}$ & 116.6 & 25.0 & 141.6 \\
& & \multicolumn{2}{c}{ Source: own calculations. }
\end{tabular}

\section{Conclusion}

Achieving reduction of economic losses and environmental damages in manure use and management will necessitate the employ of effective manure management and techniques, improved and adequate storage facilities and improved application technology of manure within farms in Turkey. This research provides information that should assist in the improvement of these examinations as well as strategies for better use and the storage of manure animal farms in Turkey. Studies have shown that both policy makers and Turkish farmers have appreciated the importance of manure used but the extent of use depicts little dynamism over the years. Some of the important constrain facing the integrated manure management in crop production: the value of manure is not well known or recognized by the farmers, extension officers and policy makers. Even with 
availability of technologies and the technical know-how, the implementation to by farmers is often challenged by the following factors: (1) unaware of manure's potential (2) inadequate knowledge about manure management practice (3) ineffective policies and (4) the unavailability of resources and investment

In order to increase manure use in crop production, legislation should pass by laws for more usage of manure and there should be incentive and motivation policies as alternative energy source for rural areas. Farmers should be educated and information should be given to them on Organic fertilizer or manure and its effects on agricultural production. Additionally, manure storage facilities should be given the needed attention and management both agronomical and economic benefits as well as environmental benefits on the farm. Mismanagement of organic manure can lead to inefficiency in farming operation and reduce crop yields as a result of delays in land preparation and planting time. Management issues for manure storage includes manure disposal, proper management of the storage structure. Besides, the increasingly high cost of chemical fertilizers and a preferred economic removal of manure ash had required research in the use of manure ash to decrease the rate of chemical fertilizer application for crop production. Therefore, government should set a target to reduce the dependence on chemical fertilizer by encouraging farmers to use manure and manure ash. It is recommended for future research to focus on economic analysis of manure management systems for Turkish livestock sectors.

Acknowledgements. A part of this study was presented as oral presentation at The XV EAAE Congress, Towards Sustainable Agri-Food Systems: Balancing between Markets and Society, August 29th - September 1st 2017 Parma, Italy and published as short abstract in the congress page. We declare that the first author was supported financially by the Scientific and Technical Research Council of Turkey (TUBITAK) under 2219 postdoctoral research program at Gent University in Belgium.

\section{References}

Araji, A., Abdo, Z., Joyse, P. (2001). Efficient use of animal manure on croplandeconomic analysis. Bioresour Technol, 79(2): 179-191.

Asai, M., Langer, V., Frederiksen, P. (2014). Responding to environmental regulations through collaborative arrangements: Social aspects of manure partnerships in Denmark. Livest Sci., 167: 370-380.

Barker, J., Hodges, S., Walls, F. (2005). Livestock manure production rates and nutrient content. North Carolina agricultural chemicals manual. Chapter X- Fertilizer Use. College of Agriculture and Life Sciences . NC State University

Casey, K.D., Bicudo, J.R., Schmidt, D.R., et al., (2006). Air quality and emissions from 
livestock and poultry production/waste management systems. In: Rice, J.M., Caldwell, D.F., Humenik, F.J. (Eds.), Animal Agriculture and the Environment: National Center for Manure and Waste Management White Papers. ASABE, p. 40.

D'Haene, K., Magyar, M., De, N.A., et al. (2007). Nitrogen and phosphorus balances of Hungarian farms. Eur J Agron, 26: 224-234.

De Clercq, P., Gertsis, A., Hofman, G. et al. (2001). Nutrient Management Legislation in European Countries. The Netherlands: Wageningen Press, 347 pp.

EPDK, (2015). Republic of Turkey energy market regulatory authority. $<$ www.epdk.org.tr//epdk-elektrik-tarifeleri-2015\#kwh-fiyat> Website. Accessed 11 December 2015

Erkmen, J., Özdemir, N. (2012). Applicability of the Contract Farming Model in Promoting the Use of Organic Fertilizer via Biogas-Unit Dairy and Fattening Farms, The Black Sea Journal of Science, 2 (6): 27-38

Erkus, A., Bulbul, M., Kiral, T. (1995). Agricultural Economics. Agricultural Economics (in Turkish). Agricultural Faculty of Ankara University Press, Ankara.

FAOSTAT, (2013). Food and Agriculture Organization of the United Nations. ResourceSTAT-Fertilizer.

$<$ http://faostat.fao.org/site/575/DesktopDefault.aspx?PageID =575\#ancor $>$ Website . Accessed 15 October 2015

Ghosh, N. (2004). Reducing dependence on chemical fertilizers and its financial implications for farmers in India. Ecol. Econ., 49(2): 149-162.

Goncagul, T. (2003). Farm animal diversity in Turkey, in OECD agriculture and biodiversity: Developing indicators for policy analysis, Paris, France. www.oecd.org/tad/env/ indicators Website. Accessed 12 July 2015

MFAL, (2015). Republic of Turkey Ministry of Food, Agriculture and Livestock. $<$ http://www.tarim.gov.tr/Konular/Bitkisel-Uretim/Bitki-Besleme-ve-TarimsalTeknolojiler/Bitki-Besleme-Istatistikleri> Website. Accessed 09 August 2015

Kacar, B. (1997). Fertilizer Knowledge. Ankara University Faculty of Agriculture Publication: Nobel Publication No 1490, Book, s. 1-441. s.57, Ankara.

Kacar, B., Katkat, V. ( 2009). Fertilizers and Fertilization Techniques. Nobel Publication No : 1119, Third Press, p.17-54. Ankara

Karyotis, T., Gucdemir, I., Akgul, S. (2014). Nitrogen fertilization plans for the main crops of Turkey to mitigate nitrates pollution. Eurasian J.Soil Sci, 3: 13-24.

Kizilaslan, H., Onurlubas, H. (2010). Potential of production of biogas from animal origin waste in Turkey (Tokat Provincial Example). J Anim Vet Adv, 9: 1083-1087.

Komiyama, T., Kobayashi, A., Yahag, M. (2012). The chemical characteristics of ashes from cattle, swine and poultry manure. J Mater Cycles Waste, 15(1):106-110

Ksawery, K., Tjalfe, G.P., Gitte, H.R., Peter, S. (2010). Plant-availability to barley of phosphorus in ash from thermally treated animal manure in comparison to other manure based materials and commercial fertilizer. Eur J Agron (33):293-303

LIFE, (2006). A guide on exploitation of agricultural residues in Turkey, agro-wasteexploitation of agricultural residues in Turkey project. EU- Life Programme Project, Project No: LIFE03 TCY/TR/000061.

MARA, (2006). Fertilizers and fertilization guide of Turkey, Republic of Turkey Ministry 
of Agriculture and Rural Affaires. General Directorate of Agricultural Research. Soil and Fertilizer Research Institute Directorate, Ankara.

Monteny, G.J., Groenestein, C.M., Hilhorst, M.A. (2001). Interactions and coupling between emissions of methane and nitrous oxide from animal husbandry. Nutr. Cycl. Agroecosyst. 60, 123-132.

Nowak, P., Shepard., R., Madison, F. (1998). Farmers and Manure Management: A critical Analysis . In: Animal Waste Utilization: Effective Use of Manure as a Soil Resource: Hatfield, J.L., Stewart, B.A., EDs.; Ann Arbor Pres: Chelsea, Michigan, pp.1-32.

OECD, (2008). Environmental performance of agriculture in OECD countries since 1990, Paris, France. < http://www.oecd.org/turkey/40807967.pdf< Website. Accessed 25 June 2015

Oskam, A.A., Burrel, T, Temel, S., et al. (2004). Turkey in the European Union Consequences for Agriculture Food Rural Areas and Structural Policy. Wageningen University, Netherland, pp: 1-253.

Pagliari, P., Rosen, C., Strock, J., et al. (2010). Phosphorus availability and early corn growth response in soil amended with Turkey manure ash. Commun Soil Sci Plant Anal., (41):1369-1382.

Pellervo, K, Lehtonen, H., Rintamäki, H. et al., (2013). Economics of manure logistics, separation and land application. Baltic Forum for Innovative Technologies for Sustainable Manure Management. Baltic Sea Region Programme of the European Union 2007-2013. Knowledge Report. p.33.

Rojas-Downing, M.M., Nejadhashemi, A.P., Harrigan, T. et al., (2017). Climate change and livestock: Impacts, adaptation, and mitigation. Clim. Risk Manag (16) : 145-163

SPO, (2000). Special Commission Report on Fertilizers. Eighth Five Year Development Plan, State Planning Organization, Publications No. 2514-SCR: 531, pp. 88. Ankara, Turkey.

Steinfeld, H., Gerber, P., Wassenaar, T., et al. (2006). Livestock's Long Shadow: Environmental Issues and Options. FAO, Rome

Swensson, C. (2003). Analyses of mineral element balances between 1997 and 1999 from dairy farms in the south of Sweden. Eur J Agron, 20 (1): 63-69.

Tittonell, P., Rufino, M.C., Janssen, B., et al. (2010). Carbon and nutrient losses from manure stored under traditional and improved practices in smallholder crop-livestock systems: Evidence from Kenya. Plant and Soil, 328. 1-2: 253-269.

Tunney, H., Csath, P., Ehlert, P. (2003). Approaches to calculating P balance at the field-scale in Europe. J Plant Nutr Soil Sci, 166: 438-446

TURKSTAT, (2015). Turkish Statistical Institute. < http://tuikapp.tuik $>$ Website. Accessed 22 September 2015

Unterschultz, R., Jeffrey, R. (2001). Economic evaluation of manure management and farm gate applications. Edmonton, Canada.

Vervaet, M., Lauwers, L., Lenders, S., et al. (2005). Effectiveness of nitrate policy in Flanders (1990-2003): Modular modelling and response analysis. In The XIth European Association of Agricultural Economists. Copenhagen, Denmark.

Yilmaz, H. (2003). Fertilizer in Turkish agriculture: Policies and economic analysis of 
fertilizer subsidy. Department of agricultural economics institute of natural and applied Sciences University of Çukurova, PhD Dissertation, Adana, Turkey.

Yilmaz, H., Demircan, V., Gul, M. (2010). Examining of chemical fertilizer use levels in terms of agriculture environment relations and economic losses in the agricultural farms: The case of Isparta, Turkey. Bulg J Agric Sci, 16: 143-157.

Yilmaz, H., Koknaroglu, H., Demircan, V. (2009). Economics of manure use as fertilizer in crop production engaged also in beef cattle Farms in Turkey. J Anim Vet Adv., 8(5): 843-852. 